\title{
UJI DAYA HAMBAT AIR PERASAN BUAH LEMON (CITRUS LIMON (L.) BURM. F.) TERHADAP PERTUMBUHAN BAKTERI AGGREGATIBACTER ACTINOMYCETEMCOMITANS
}

\author{
Umi Ghoni Tjiptoningsih \\ Departeman Periodonsia, Fakultas Kedokteran Gigi Universitas Prof. Dr. Moestopo (Beragama), Jakarta \\ Korespondensi: umighonitjiptoningsih@dsn.moestopo.ac.id
}

\begin{abstract}
ABSTRAK
Latar belakang: sebanyak 74,1\% masyarakat Indonesia mengalami penyakit periodonsium. Data ilmiah menegaskan peran Aggregatibacter actinomycetemcomitans sebagai bakteri patogen oportunistik yang menjadi faktor etiologi periodontitis agresif lokal. Air perasan buah lemon (Citrus limon (L.)Burm. f.) memiliki banyak senyawa bioaktif seperti limonen, flavonoid, asam sitrat, dan tanin yang memiliki sifat antibakteri. Tujuan: penelitian ini bertujuan memberikan penjelasan mengenai daya hambat air perasan buah lemon $25 \%, 50 \%, 100 \%$ terhadap pertumbuhan bakteri Aggregatibacter actinomycetemcomitans. Metode: penelitian ini bersifat eksperimental laboratoris secara in vitro. Penelitian ini menggunakan air perasan buah lemon 25\%,50\%, 100\% dan kontrol positif (klorheksidin 0,2\%). Uji daya hambat dilakukan dengan metode difusi agar menggunakan kertas cakram. Plat agar diinkubasi pada lingkungan anaerob pada suhu $37^{\circ} \mathrm{C}$ selama 24 jam. Perhitungan daya hambat dilakukan dengan mengukur zona terang di sekitar cakram kertas menggunakan jangka sorong digital. Hasil: uji t-independent menunjukkan perbedaan Aggregatibacter actinomycetemcomitansn yang tidak signifikan antara kelompok perlakuan dan kelompok kontrol $(\mathrm{p}>0,05)$. Daya hambat tertinggi pada air perasan buah lemon $25 \%, 50 \%$, dan $100 \%$ adalah $8,775 \mathrm{~mm}$. Kesimpulan: air perasan buah lemon (Citrus limon (L.) Burm. f.) dapat menghambat pertumbuhan bakteri Aggregatibacter actinomycetemcomitans (Aa).
\end{abstract}

Kata kunci: air perasan buah lemon, Aggregatibacter actinomycetemcomitans, metode difusi cakram kertas

\begin{abstract}
Background: there is $74.1 \%$ of Indonesia's population suffers from periodontium disease. Scientific data confirms the role of Aggregatibacter actinomycetemcomitans as an opportunistic pathogenic bacterium that becomes etiological factor of local aggresive periodontitis. Lemon juice (Citrus limon (L.) Burm. f.) has many bioactive compounds such as limonene, flavonoids, citric acid, and tannin which has antibacterial characteristics. Purpose : the purpose of this study is to have an explanation on antibacterial effects of lemon juice with the on centration of $25 \%, 50 \%, 100 \%$ on the growth of Aggregatibacter actinomycetemcomitans bacterium. Methods: this research is a laboratory experiment that is done in vitro. This research is done using $25 \%, 50 \%, 100 \%$ lemon juice and positive control (chlorhexidine $0,2 \%)$. The inhibition test is done by disc diffusion method using paper discs. The agar disc was incubated in an anaerobic environement at $370 \mathrm{C}$ for 24 hours. The result of inhibitory potential will be calculated based on the area of the clear zone around the paper disc using a digital caliper. Result: t-test independent results showed no significant difference between the treatment group and the ontrol group $(p>0,05)$. The highest inhibition power in lemon juice $25 \%, 50 \%$, and $100 \%$ was $8.775 \mathrm{~mm}$. Conclusion: there is inhibitory potential of $25 \%, 50 \%$ dan $100 \%$ lemon juice on the growth of Aggregatibacter actinomycetemcomitans bacterium.
\end{abstract}

Keywords: lemon juice, Aggregatibacter actinomycetemcomitans, paper disc diffusion method

\section{PENDAHULUAN}

$\mathrm{D}$ ata Riset Kesehatan Dasar pada tahun 2018, terdapat 57,6\% penduduk Indonesia yang mempunyai masalah kesehatan gigi dan mulut. Karies gigi dan penyakit periodonsium adalah penyakit gigi dan mulut yang paling banyak terjadi pada masyarakat Indonesia dengan persentase sebesar $88,8 \%$ penduduk Indonesia mengalami karies gigi dan $74,1 \%$ mengalami periodontitis. Penyakit periodonsium yang paling sering terjadi di masyarakat adalah gingivitis dan periodontitis. ${ }^{1,2,3,4}$

Periodontitis adalah suatu penyakit inflamasi 
pada jaringan pendukung gigi yang disebabkan oleh mikroorganisme atau sekelompok mikroorganisme spesifik sehingga mengakibatkan terjadinya kerusakan progresif pada ligamen periodonsium dan tulang alveolar dengan membentuk poket, resesi, atau keduanya. Menurut American Academy of Periodontology tahun 1999, penyakit periodonsium diklasifikasikan menjadi periodontitis kronis, periodontitis agresif, dan periodontitis sebagai manifestasi penyakit sistemik. Periodontitis adalah penyakit yang bersifat multifaktorial yang pada umumnya terjadi akibat ketidakseimbangan host dan mikroorganisme. ${ }^{1,5,6}$

Periodontitis agresif terjadi lebih cepat dibandingkan dengan periodontitis kronis. Periodontitis agresif umumnya menyerang individu pada usia di bawah 30 tahun atau pada usia yang lebih tua sehingga dapat dibedakan dengan periodontitis kronis berdasarkan usia pasien. Aktivitas penyakit ini ditandai oleh adanya kerusakan tulang dan kehilangan perlekatan yang terjadi sangat cepat dengan akumulasi faktor lokal yang minimal, yaitu plak dan kalkulus. 1,7,8

Data ilmiah secara jelas menegaskan peran Aggregatibacter actinomycetemcomitans (Aa) sebagai bakteri patogen oportunistik yang menjadi faktor etiologi periodontitis agresif lokal dan merupakan bagian darifloranormalyang berkolonisasipadamukosa rongga mulut, gigi, dan orofaring. Aggregatibacter actinomycetemcomitans (Aa) adalah bakteri Gram negatif berbentuk kokobasil, bersifat non motil, dan anaerob fakultatif dengan beragam potensi faktor dan mekanisme virulensi yang membantu progresivitas penyakit seperti mekanisme penghindaran kekebalan tubuh yang dapat membawa kerusakan jaringan oleh mekanisme baru lainnya dengan mengikat matriks host dan menginvasi sel host. ${ }^{1,5,9}$

Perawatan yang dapat dilakukan dalam merawat pasien periodontitis agresif antara lain melalui tindakan nonbedah, bedah, dan perawatan antimikroba. Penggunaan antibiotik yang kurang tepat dapat mengakibatkan bakteri resisten terhapan obat antibiotik yang telah diberikan. Menurut Ardila, penggunaan obat antibiotik yang tidak tepat atau berlebihan dapat membuat bakteri resisten. 1,5 10,11

Penggunaan bahan alamiah sebagai obat herbal dinilai lebih aman daripada penggunaan obat modern karena efek sampingnya yang relatif lebih kecil jika digunakan secara tepat. Selain untuk pengobatan, produk herbal juga dapat digunakan sebagai pencegahan terjadinya penyakit periodonsium. Salah satu tanaman herbal yang sering dimanfaatkan sebagai obat herbal adalah buah lemon. Air perasan buah lemon (Citrus limon (L.) Burm. f.) memiliki banyak senyawa bioaktif seperti flavonoid, karotenoid, limonoid, tanin, dan terpenoid. Senyawa bioaktif yang terkandung dalam lemon masing-masing memiliki sifat antibakteri. ${ }^{1,12,13,14}$

Penelitian yang telah dilakukan oleh Pamela
Lolita Berti membuktikan bahwa air perasan buah lemon (Citrus limon (L.) Burm. f.) konsentrasi 60\%, $70 \%, 80 \%, 90 \%$, dan $100 \%$, memiliki daya antibakteri terhadap Porphyromonas gingivalis. Penelitian yang telah dilakukan oleh Yoshiaki Miyake dan Masanori Hiramitsu menjelaskan bahwa substansi antibakteri yang telah diisolasi dan diekstraksi dari kulit jeruk lemon dapat menghambat bakteri oral penyebab karies dan periodontitis, seperti Streptococcus mutans, Prevotella intermedia, dan Porphyromonas gingivalis. ${ }^{1,15-17}$

Berdasarkan beberapa teori dan penelitian yang telah ada, peneliti tertarik untuk melakukan penelitian mengenai daya hambat air perasan buah lemon (Citrus limon (L.) Burm. f.) 25\%, 50\%, 100\% terhadap pertumbuhan bakteri Aggregatibacter actinomycetemcomitans (Aa). Pengujian aktivitas antibakteri ini dilakukan dengan metode difusi cakram kertas.

Air perasan buah lemon (Citrus limon (L.) Burm. f.) memiliki banyak senyawa bioaktif seperti flavonoid, karotenoid, limonoid, tanin, terpenoid, limonen, dan asam sitrat. Senyawa bioaktif yang terkandung dalam lemon masing-masing memiliki sifat antibakteri. Aggregatibacter actinomycetemcomitans (Aa) merupakan bakteri Gram negatif fakultatif anaerob yang berperan dalam menyebabkan terjadinya periodontitis agresif dan periodontitis kronis. Menurut penelitian yang telah dilakukan oleh Natasya Angelyna Batubara, air perasan buah jeruk lemon (Citrus limon) dapat menghambat jumlah koloni Staphylococcus aureus secara in vivo. Pamela Lolita Berti juga telah membuktikan bahwa air perasan buah lemon (Citrus limon (L.) Burm.f.) yang mengandung banyak senyawa bioaktif menunjukkan daya hambat terhadap pertumbuhan bakteri Porphyromonas gingivalis yang menjadi bakteri patogen periodontis kronis. ${ }^{1,13-15,17,18}$

\section{METODE PENELITIAN}

Jenis penelitian yang dilakukan adalah eksperimental laboratoris dengan rancangan penelitian the post-test only control group design yaitu suatu metode dengan melakukan pengamatan dan pengukuran pada kelompok kontrol dan kelompok perlakuan pada waktu yang telah ditentukan. Tujuan dari rancangan penelitian ini adalah untuk mengetahui dampak yang ditimbulkan oleh suatu perlakuan. Pembuatan dan pengenceran air perasan buah jeruk lemon, pembiakan dan pengujian bakteri dilakukan Balai Bioteknologi Badan Pengkajian dan Penerapan Teknologi (BPPT). Waktu penelitian yaitu bulan Juli sampai Agustus 2019. Dimulai dari pencarian alat dan bahan penelitian, persiapan penelitian, kemudian dilakukan penelitian, analisa data dan penentuan hasil, serta pembahasan hasil penelitian. Sampel penelitian yang digunakan adalah biakan bakteri Aggregatibacter actinomycetemcomitans yang tersedia di Laboratorium Mikrobiologi Universitas Indonesia. Jumlah sampel penelitian eksperimental 
dihitung dengan menggunakan rumus penentuan besar sampel Federer, yaitu sebagai berikut.

\section{$(t-1)(r-1) \geq 15$}

Keterangan:

t: jumlah perlakuan

r: jumlah replikasi

Penelitian ini menggunakan 5 kelompok perlakuan yaitu:

1. Kelompok 1: Air perasan buah jeruk lemon $100 \%$

2. Kelompok 2: Air perasan buah jeruk lemon 50\%

3. Kelompok 3: Air perasan buah jeruk lemon $25 \%$

4. Kelompok 4: klorhexidin sebagai kontrol positif

5. Kelompok 5: Media MHA sebagai kontrol negatif Jadi, jumlah perlakuan $(\mathrm{t})=5$

Jumlah replikasi sampel (r) minimum untuk masing-masing kelompok sampel adalah 5, artinya diperlukan masing-masing 5 sampel untuk setiap kelompok sampel agar tidak terjadi bias. Dengan demikian, total sampel yang diperlukan untuk penelitian ini adalah 25 sampel. Air perasan jeruk lemon yang berasal dari buah jeruk lemon dengan kriteria inklusi sebagai berikut: segar, sehat dan bebas dari hama, tidak busuk, jeruk lemon lokal.

Biakan bakteri Aggregatibacter actinomycetemcomitans yang tersedia di Laboratorium Mikrobiologi Universitas Indonesia. Air perasan jeruk lemon yang berasal dari buah jeruk lemon dengan kriteria eksklusi sebagai berikut: layu, terkena hama, busuk.

Pembuatan Air Perasan Buah Jeruk Lemon: ${ }^{19}$

1. Jeruk lemon ditimbang sebanyak $0,5 \mathrm{~kg}$ kemudian diambil sari buahnya menggunakan alat pemeras jeruk yang telah disterilkan.

2. Sari buah disaring menggunakan kertas saring untuk memisahkan sari buahnya dengan ampas.

3. Sari buah yang sudah terpisah dari ampasnya disentrifugasi dalam centrifuge sehingga terbentuk 2 lapisan, yaitu lapisan bening di bagian atas dan lapisan keruh di bagian bawah.

4. Ambil lapisan bening dari air perasan buah jeruk lemon tersebut untuk digunakan sebagai bahan penelitian.
Lemon: ${ }^{1,15,18,19}$

Pengenceran Air Perasan Buah Jeruk

1. Pengenceran konsentrasi air perasan buah jeruk lemon dilakukan di dalam laminar air flow menggunakan mikropipet yang diberi tip.

2. Untuk mendapatkan konsentrasi masing-masing larutan, maka dilakukan pengenceran dengan menggunakan bahan pelarut aquades steril menggunakan rumus pengenceran sebagai berikut.

$$
V_{1} M_{1}=V_{2} M_{2}
$$

Keterangan:

V1 : Volume jus jeruk lemon yang akan diambil untuk diencerkan

V2 : Volume jus jeruk lemon yang akan dibuat

M1 : Konsentrasi jus jeruk lemon yang akan diencerkan

M2 : Konsentrasi jus jeruk lemon yang akan dibuat

Sehingga didapatkan data sebagai berikut.

a. Air perasan jeruk lemon $100 \%$ adalah $10 \mathrm{ml}$ air perasan jeruk lemon tanpa ditambahkan aquades steril.

b. Air perasan jeruk lemon $50 \%$ adalah sebanyak $5 \mathrm{ml}$ air perasan jeruk lemon yang ditambahkan dengan $5 \mathrm{ml}$ aquades steril.

c. Air perasan jeruk lemon 25\% adalah sebanyak 2,5 ml air perasan jeruk lemon yang ditambahkan dengan 7,5 $\mathrm{ml}$ aquades steril.

3. Larutan air perasan jeruk lemon dengan konsentrasi $100 \%, 50 \%$, dan 25\% masing-masing dimasukkan ke dalam botol kaca yang telah disterilkan.

4. Simpan dalam lemari pendingin untuk menjaga kesegaran larutan.

Pembuatan Media Mueller Hinton Agar:

1. Timbangan distandardisasi dengan menggunakan kertas.

2. Larutkan 7.2 gram bubuk kedalam $144 \mathrm{ml}$ aquades steril untuk membuat 24 petri $(20 \mathrm{ml} /$ petri).

3. Panaskan di atas tungku pemanas magnetik sampai mendidih.

4. Media yang telah masak, disterilkan di dalam autoklaf selama 15 menit dengan tekanan udara 2 atm suhu $121^{\circ} \mathrm{C}$.

5. Simpan media dalam lemari pendingin.

6. Jika media ingin digunakan maka harus dipanaskan 


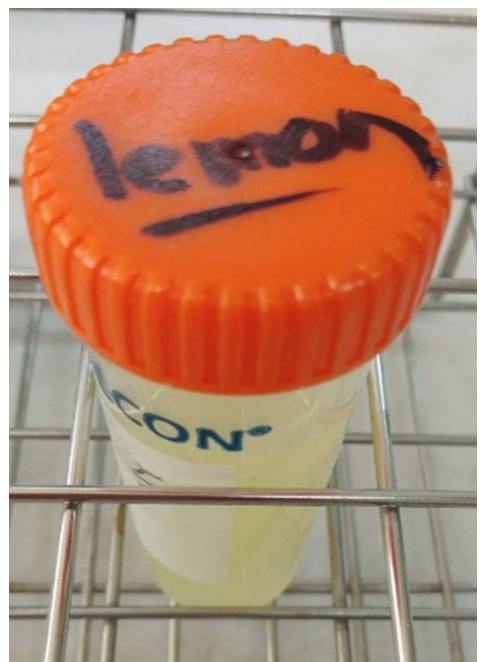

Gambar 1. Air perasan jeruk lemon

kembali hingga mendidih lalu dituangkan ke dalam masing-masing petri dan dibiarkan hingga dingin.

Pembiakan Aggregatibacter actinomycetemcomitans pada media BHIB:

1. Pembuatan suspensi bakteri dilakukan sesuai standard kekeruhan 0,5 Mc Farland (1,5 x $10^{8} \mathrm{CFU} /$ ml) yaitu beberapa koloni bakteri Aggregatibacter actinomycetemcomitans diambil dengan ose steril.

2. Larutkan dalam $10 \mathrm{ml}$ media cair BHIB pada tabung reaksi.

3. Mulut tabung dilewatkan di atas lampu spiritus yang sedang menyala.

4. Homogenkan di atas sentrifus.

5. Tabung reaksi tersebut ditutup dengan kapas lalu dimasukkan ke dalam desikator dan diinkubasi dengan suhu $37^{\circ} \mathrm{C}$ selama 24 jam.

6. Pertumbuhan Aggregatibacter actinomycetemcomitans ditandai dengan adanya kekeruhan pada media.

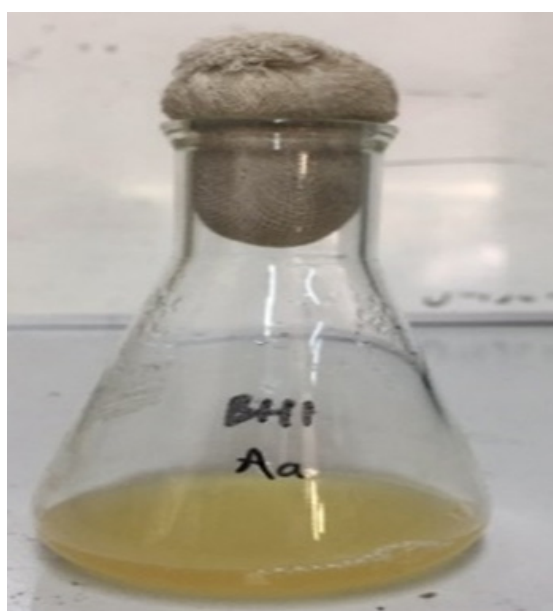

Gambar 3. Media Brain Heart Infusion (BHIB)

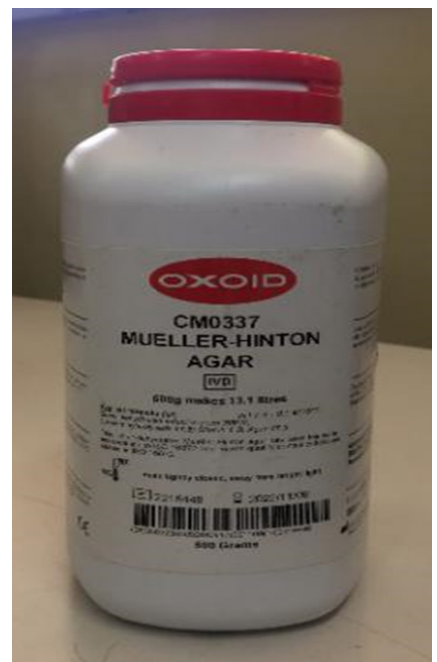

Gambar 2. Media Mueller Hinton Agar (MHA)

7. Setelah 24 jam, suspensi Aggregatibacter actinomycetemcomitans dalam tabung reaksi divibrasi dengan menggunakan thermolyne

8. Ukur absorbansinya dengan standard kekeruhan 0,5 Mc Farland dengan absorbansi 0,05 dan panjang gelombang $560 \mathrm{~nm}$ dengan menggunakan spektrofotometer.

Pemberian Kode Label pada Cawan Petri:

Pemberian kode label pada 5 cawan petri yang steril dilakukan dalam laminar air flow untuk mencegah kontaminasi dengan lingkungan luar. Masing-masing cawan petri diberi kode label nomor urut cawan petri dari 1 sampai 5. Kemudian, pada bagian bawah masingmasing cawan petri diberi keterangan label yang terdiri dari 5 macam, yaitu kode $\mathrm{K}$ - untuk kontrol negatif (akuades steril), $\mathrm{K}+$ untuk kontrol positif (Media MHA), L100 untuk air perasan buah jeruk lemon dengan konsentrasi 100\%, L50 untuk air perasan buah jeruk lemon dengan konsentrasi 50\%, dan L25 untuk air perasan buah jeruk lemon dengan konsentrasi $25 \%$.

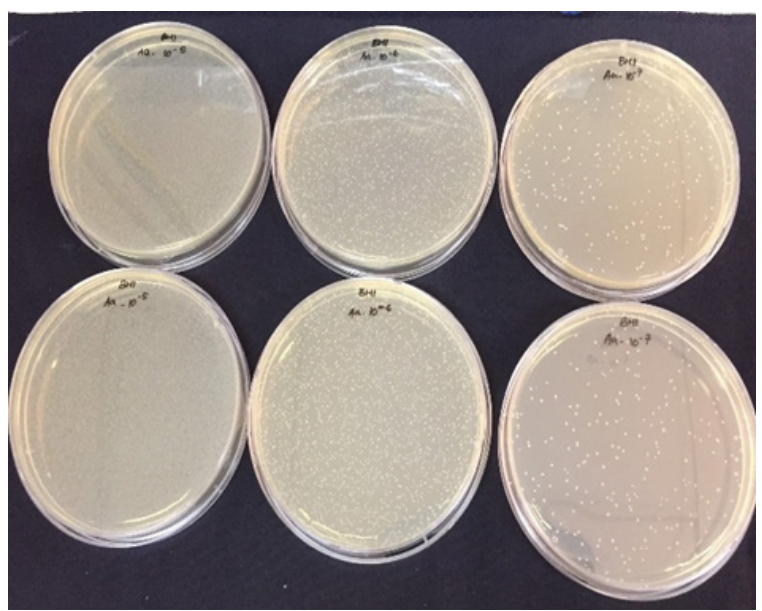

Gambar 4. Media Brain Heart Infusion Agar 
Pengujian air perasan buah jeruk lemon terhadap Aggregatibacter Actinomycetemcomitans dengan Metode Difusi Cakram Kertas:

1.Siapkan cawan petri yang telah berisi media MHA dan cakram kertas.

2. Masukkan dan rendam selama 15 menit cakram kertas ke dalam larutan air perasan buah jeruk lemon konsentrasi $100 \%, 50 \%, 25 \%$, dan akuades steril sebagai kontrol negatif.

3. Oleskan larutan bakteri yang telah distandardisasi pada media pertumbuhan MHA dengan menggunakan Hockey stick.

4. Letakkan cakram kertas yang telah direndam di atas permukaan MHA secara higienis di dalam laminar air flow sesuai dengan label.

5. Tutup cawan petri, lalu masukkan dengan posisi terbalik ke dalam desikator untuk menciptakan kondisi anaerob

6. Masukkan desikator ke dalam inkubator untuk diinkubasi selama 24 jam pada suhu $37^{\circ} \mathrm{C}$.

7. Setelah 24 jam diinkubasi, pertumbuhan bakteri ditandai adanya titik-titik koloni pada media MHA.

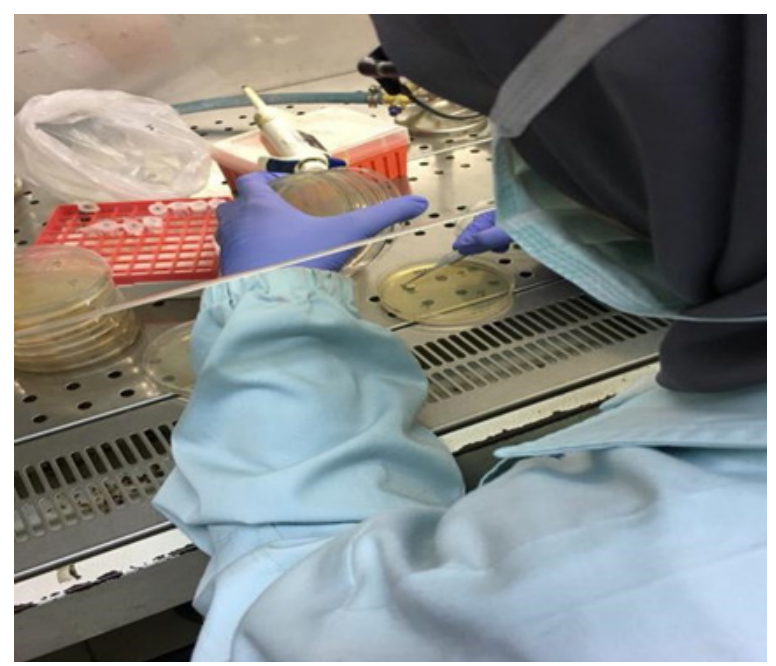

Gambar 5. Peletakkan cakram kertas dalam air perasan buah lemon di atas MHA

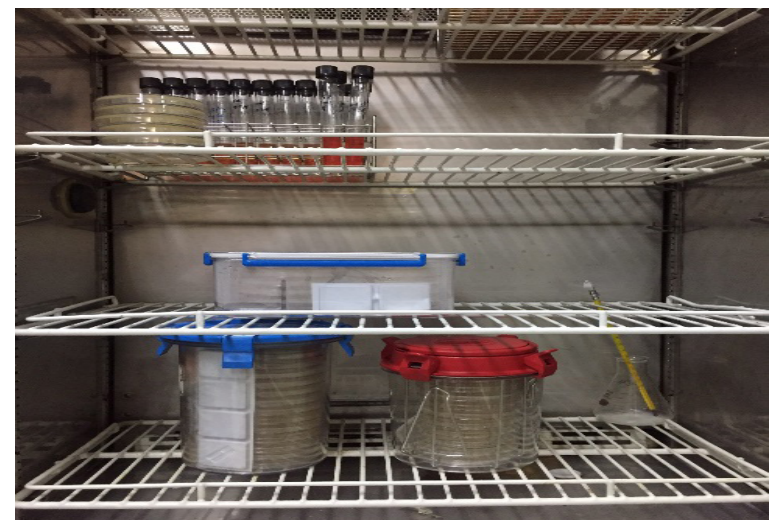

Gambar 6. Cawan petri di inkubasi dalam inkubator selama 24 jam pada suhu $37^{\circ} \mathrm{C}$.

\section{Pengukuran Zona Hambat ${ }^{20}$}

1. Setelah dilakukan inkubasi selama 24 jam, kemudian dilakukan pengukuran diameter zona hambat di sekitar cakram kertas pada masingmasing kelompok penelitian dengan menggunakan rasio perbandingan antara besar diameter terluar zona hambat dengan diameter kertas cakram menggunakan jangka sorong.

2. Pengukuran dilakukan dengan menghitung diameter rata-rata zona hambat dengan rumus hasil pengurangan diameter vertikal (a) dan diameter kertas saring (c) dijumlahkan dengan hasil pengurangan diameter horizontal (b) dan diameter kertas saring (c) lalu dibagi 2.

3. Dari hasil perhitungan tersebut, nilai yang didapatkan akan dimasukkan ke dalam kriteria klasifikasi efektivitas suatu zat antibakteri Menurut Greenwood sebagai berikut.

a. Diameter $<10 \mathrm{~mm}$ : daya hambat tidak ada (bakteri resisten)

b. Diameter 10-15 $\mathrm{mm}$ : daya hambat lemah (bakteri cukup resisten)

c. Diameter 16-20 $\mathrm{mm}$ : daya hambat sedang (bakteri rentan)

d. Diameter $>20 \mathrm{~mm}$ : daya hambat kuat (bakteri sangat rentan)

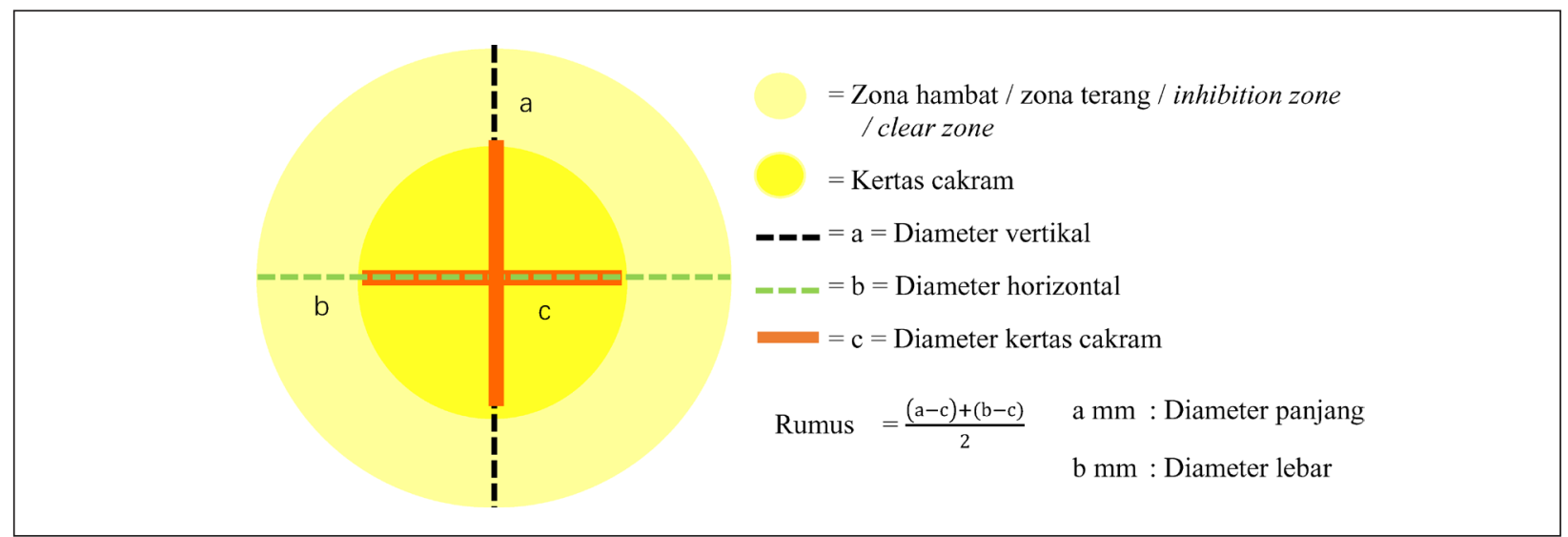

Gambar 7. Cara pengukuran zona hambat 


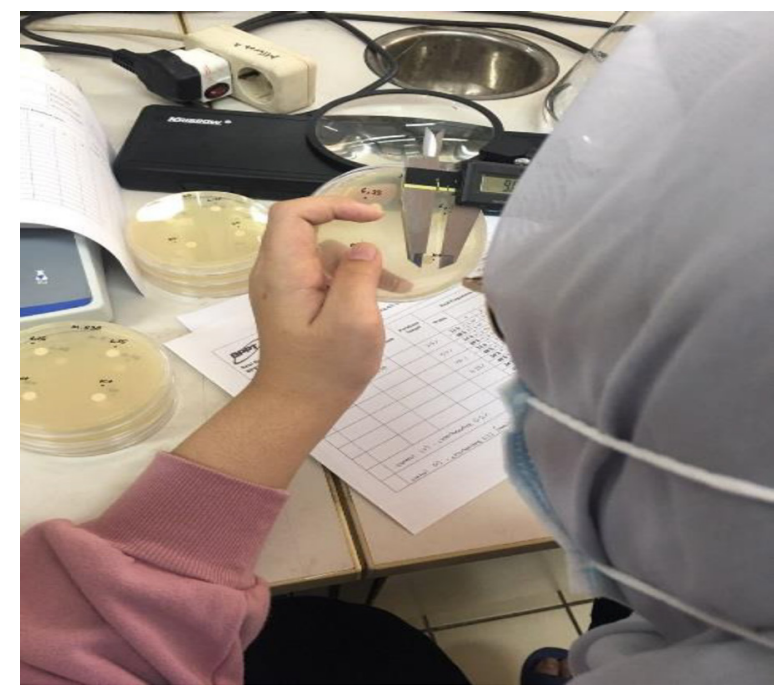

Gambar 8. Pengukuran diameter zona hambat dengan jangka sorong digital

\section{HASIL PENELITIAN}

Untuk mengetahui daya hambat air perasan buah lemon (Citrus limon(L) Burm. f.) 25\%, 50\%, dan 100\% terhadap bakteri Aggregatibacter actinomycetemcomitans (Aa) digunakan metode difusi. Daya hambat ditandai dengan tidak tumbuhnya bakteri Aggregatibacter actinomycetemcomitans (Aa) di sekitar cakram yang berupa zona terang. Selanjutnya, zona terang akan di ukur dengan jangka sorong digital dalam satuan milimeter.

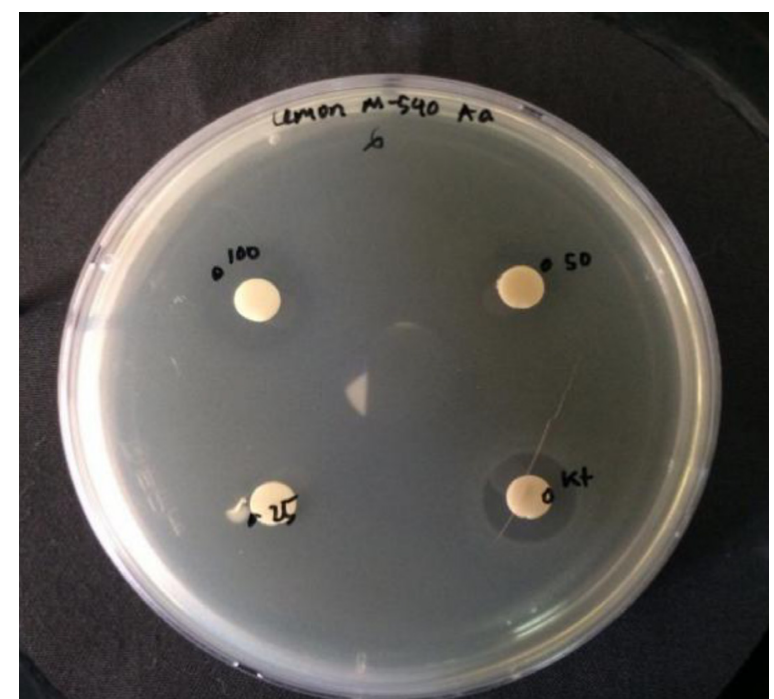

Gambar 9. Hasil penelitian air perasan buah lemon
Tabel 1. Hasil Uji t independent untuk perbandingan ekstrak lemon dan chlorhexidine (VERTIKAL)

\begin{tabular}{lccc}
\hline & mean & SD & p \\
\hline Ekstrak lemon 100 & 13.8383 & 0.6070 & $0.002^{*}$ \\
Chlorhexidine & 12.5217 & 0.5267 & \\
\hline Ekstrak lemon 50 & 6.6317 & 0.2912 & $0.000^{*}$ \\
Chlorhexidine & 12.5217 & 0.5267 & \\
\hline Ekstrak lemon 25 & 6.0000 & 0.0000 & $0.000^{*}$ \\
Chlorhexidine & 12.5217 & 0.5267 & \\
\hline
\end{tabular}

$* \mathrm{p} \leq 0.05$, CI 95\%, Independent t-test

Tabel 2. Hasil Uji t independent untuk perbandingan ekstrak lemon dan chlorhexidine (HORIZONTAL)

\begin{tabular}{lccc}
\hline & mean & SD & p \\
\hline Ekstrak lemon 100 & 13.9850 & 1.0528 & $0.007^{*}$ \\
Chlorhexidine & 12.2533 & 0.6599 & \\
\hline Ekstrak lemon 50 & 6.7750 & 0.2515 & $0.000^{*}$ \\
Chlorhexidine & 12.2533 & 0.6599 & \\
\hline Ekstrak lemon 25 & 6.0000 & 0.0000 & $0.000^{*}$ \\
Chlorhexidine & 12.2533 & 0.6599 & \\
\hline
\end{tabular}

$* \mathrm{p} \leq 0.05$, CI 95\%, Independent t-test

Pada penelitian ini dapat dilakukan uji $\mathrm{t}$ independent karena syarat untuk melakukan analisa data dengan uji $t$ independent adalah data harus terdistribusi normal dan variannya homogen. didapatkan $\mathrm{p}>0,05$. Maka dari itu tidak terdapat perbedaan bermakna antara daya hambat chlorhexidine dan daya hambat ekstrak buah lemon $25 \%, 50 \%$, dan $100 \%$. Berdasarkan hasil penelitian diketahui terdapat anti daya anti bakteri ekstrak buah lemon $25 \%$, 50\%, dan 100\% terhadap bakteri Aggregatibacter actinomycetemcomitans $(\mathrm{p}=0,076)$ dan chlorhexidine yang memiliki daya antibakteri terhadap bakteri Aggregatibacter actinomycetemcomitans.

Rerata daya hambat air perasan buah lemon $25 \%, 50 \%$, dan $100 \%$ terhadap pertumbuhan bakteri Aggregatibacter actinomycetemcomitans (Aa) yaitu 2,871 $\mathrm{mm}$, lebih kecil dibandingkan dengan rerata daya hambat chlorhexidine, yaitu $6,387 \mathrm{~mm}$. daya hambat tertinggi pada air perasan buah lemon $25 \%$, $50 \%$, dan $100 \%$ adalah $8,775 \mathrm{~mm}$ dan yang terendah adalah $0 \mathrm{~mm}$, sedangkan pada chlorhexidine daya hambat tertinggi adalah $6,955 \mathrm{~mm}$ dan yang terendah adalah 5,755 $\mathrm{mm}$. 


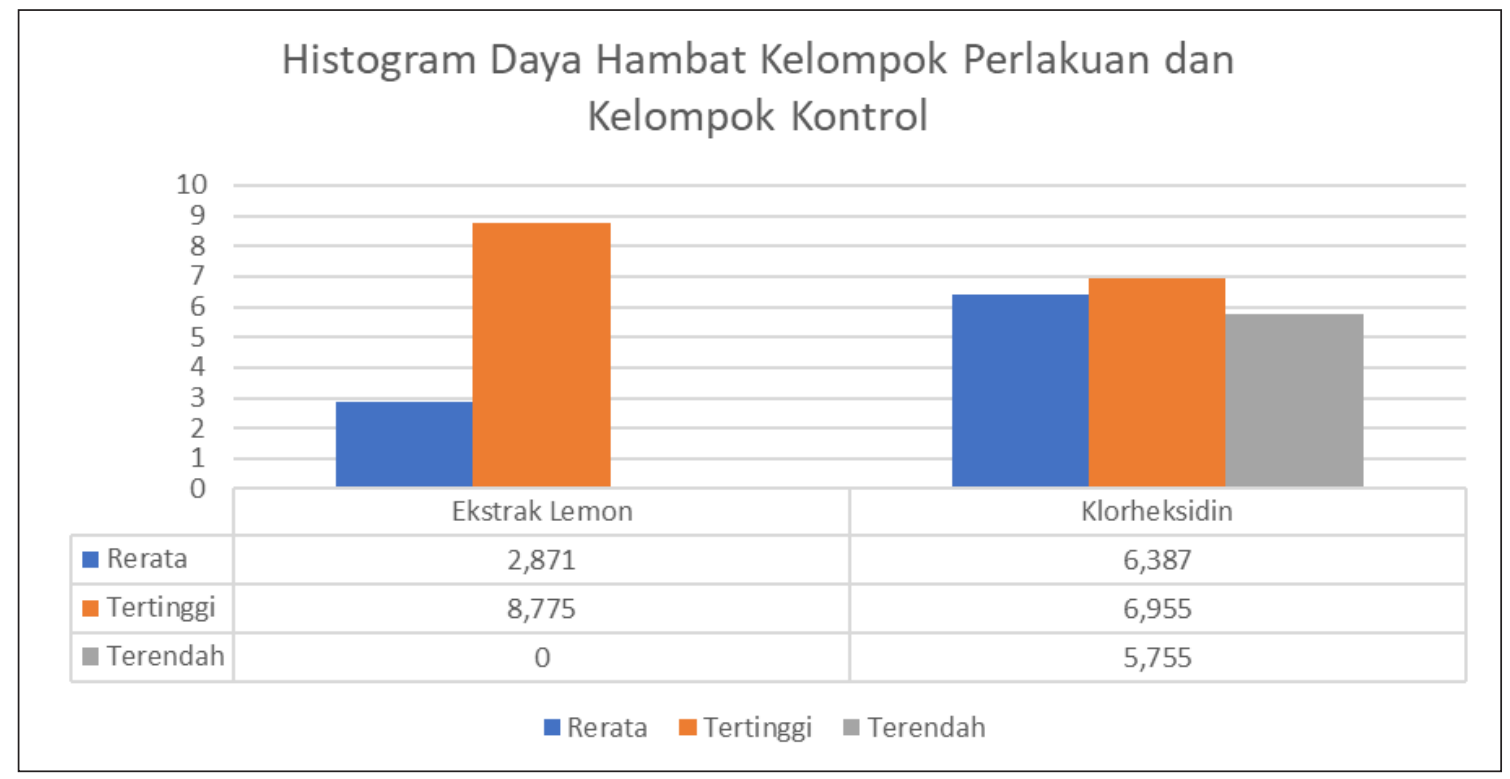

Gambar 10. Histogram daya hambat kelompok perlakuan dan kelompok control terhadap bakteri Aggregatibacter actinomycetemcomitans.

Tabel 3. Frekuensi Efektifitas Antibakteri Menurut Davis dan Stout

\begin{tabular}{|c|c|c|c|}
\hline & $\begin{array}{c}\text { Kategori Zona } \\
\text { Hambat }\end{array}$ & Frekunsi & $\begin{array}{c}\text { Persen } \\
(\%)\end{array}$ \\
\hline $\begin{array}{c}\text { Kelompok Air } \\
\text { Perasan Buah } \\
\text { Lemon } \\
\mathbf{2 5 \%}, \mathbf{5 0 \% , 1 0 0 \%}\end{array}$ & Lemah & 5 & 50 \\
\hline \multirow[t]{2}{*}{$\begin{array}{c}\text { Kelompok } \\
\text { Chlorheksidin } \\
(\mathrm{K}+)\end{array}$} & Lemah & 5 & 50 \\
\hline & & 10 & 100 \\
\hline
\end{tabular}

Tabel di atas menunjukkan bahwa dari 10 perlakuan uji terdapat 5 sampel air perasan buah lemon $25 \%$, 50\%, dan 100\% dan 5 sampel chlorhexidine yang memiliki respon hambatan pertumbuhan bakteri yang lemah berdasarkan kualifikasi efektivitas antibakteri menurut Davis dan Stout. Berdasarkan penjelasan di atas, dapat dikatakan bahwa air perasan buah lemon 25\%, 50\%, dan 100\% dan chlorhexidine sama-sama memiliki daya hambat terhadap pertumbuhan bakteri Aggregatibacter actinomycetemcomitans (Aa).

\section{PEMBAHASAN}

Penelitian ini bertujuan untuk memberikan penjelasan mengenai daya hambat air perasan buah lemon (Citrus limon (L.) Burm.f.) 25\%, 50\%, dan $100 \%$ terhadap pertumbuhan bakteri Aggregatibacter actinomycetemcomitans (Aa). Penelitian ini diawali dengan pembuatan air perasan buah lemon. Buah lemon yang digunakan dalam penelitian ini adalah buah lemon yang sudah matang dan segar. Buah lemon diambil sari buahnya menggunakan alat pemeras jeruk yang telah disterilkan dan sari buahnya disaring menggunakan kertas saring untuk memisahkan sari buah dengan ampas. Sari buah disentrifugasi dalam centrifuge sehingga terbentuk 2 lapisan, yaitu lapisan bening di bagian atas dan lapisan keruh di bagian bawah. Lapisan bening dari air perasan buah jeruk lemon tersebut digunakan sebagai bahan penelitian.

Kosentrasi yang digunakan pada penelitian ini adalah $25 \%$, 50\%, dan $100 \%$ dengan pengeceran menggunakan bahan pelarut aquades steril. Pemilihan konsentrasi dan prosedur penelitian yang diguankan pada penelitian ini lebih kurang berpedoman pada penelitian sebelumnya yang dilakukan oleh Pamela Lolita Berti yang membuktikan bahwa air perasan jeruk lemon (Citrus limon (L.) Burm.f.) konsentrasi $60 \%, 70 \%, 80 \%, 90 \%$ dan 100\%, memiliki daya antibakteri terhadap Porphyromonas gingivalis. ${ }^{1,15}$

Bakteri Aggregatibacter actinomycetemcomitans (Aa) dipilih sebagai sampel penelitian karena merupakan bakteri Gram negative fakultatif anaerob berbentuk basil yang berperan dalam menyebabkan terjadinya periodontitis agresif dan periodontitis kronis. Bakteri ini dapat merusak jaringan dengan cara merangsang inflamasi, menyebabkan destruksi jaringan dan menghambat penyembuhan jaringan. Habitat asli bakteri ini adalah dalam rongga mulut. Bakteri lain yang dapat menyebabkan terjadinya penyakit periodonsium ialah Porphyromonas gingivalis, Prevotela intermedia, Fusobacterium nucleatum yang merupakan bakteri Gram negatif. Namun, bakteri yang paling dominan yang ditemukan pada penderita periodontitis ialah bakteri Aggregatibacter actinomycetemcomitans (Aa). 1,9,17, 19-22 
Bakteri Aggregatibacteractinomycetemcomitans (Aa) yang digunakan dalam penelitian ini adalah stok kultur bakteri sebanyak 1,5 ml yang disimpan dalam Eppendorf tube yang didapatkan dari Laboratorium Biologi Oral Fakultas Kedokteran Gigi Universitas Indonesia. Stok kultur bakteri ini dibiakkan pada media BHI dan diinkubasi selama 24 jam dengan suhu $37^{\circ} \mathrm{C}$.

Metode pengujian aktivitas antibakteri yang dilakukan untuk mengetahui daya hambat air perasan buah lemon (Citrus limon (L.) Burm.f.) 25\%, 50\%, dan 100\% terhadap pertumbuhan bakteri Aggregatibacter actinomycetemcomitans (Aa) adalah dengan metode difusi cakram kertas (paper disk) atau metode Kirby Bauer pada media Mueller Hilton Agar (MHA). Metode ini adalah cara yang paling sering digunakan, mudah dilakukan, dan biayanya relatif murah dalam menentukan kepekaan kuman terhadap berbagai macam kandungan. ${ }^{1,21}$

Mueller Hilton Agar (MHA) digunakan sebagai media dalam penelitian ini karena dianggap sebagai media terbaik untuk pengujian rutin kerentanan bakteri dan telah direkomendasikan oleh WHO untuk uji antibakteri, terutama untuk bakteri aerob dan anaerob fakultatif untuk makanan dan materi klinis. 1,22

Cangkram kertas direndam dalam air perasaan buah lemon $25 \%$, 50\%, dan $100 \%$ selama 15 menit dan diletakkan di atas media Mueller Hilton Agar (MHA) dan diinkubasi selama 24 jam pada suhu $37^{\circ} \mathrm{C}$. kemudian dilakukan pengukuran diameter zona terang yang terbentuk disekitar cakram kertas pada masingmasing kelompok penelitian dengan menggunakan rasio perbandingan antara besar diameter terluar zona terang dengan diameter cakram kertas menggunakan jangka sorong digital. Ambil Rerata diameter zona terang untuk menunjukan daya hambat pada pertumbuhan bakteri.

Hasil penelitian menunjukan bahwa air perasan buah lemon (Citrus lemon (L.) Burm f.) 25\%, 50\%, dan $100 \%$ dan chlorhexidine $(\mathrm{K}+)$ mempunyai zona terang di sekitar cakram kertas yang menunjukan bahwa kedua kelompok memiliki daya hambat terhadap pertumbuhan bakteri Aggregatibacter actinomycetemcomitans (Aa). Berdasarkan hasil uji perbedaan non parametrik Mann-Whitney yang telah dilakukan, menunjukan bahwa air perasan buah lemon $25 \%, 50 \%$, dan $100 \%$ memiliki daya hambat yang lebih lemah tetapi tidak signifikan dibandingkan dengan daya hambat chlorhexidine terhadap pertumbuhan bakteri Aggregatibacter actinomycetemcomitans (Aa).

Pada penelitian ini, chlorhexidine $0,2 \%$ digunakan sebagai control atau pembanding, chlorhexidine glukonat merupakan derivat bisbiguanida yang efektif dan mempunyai spektrum luas, bekerja cepat dan toksisitas rendah dan merupakan salah satu zat anti mikroba yang telah menjadi gold standart untuk menghambat pertumbuhan plak gigi dan mencegah terjadinya penyakit periodontal. Chlorhexidine merupakan suatu anti septik dan desinfektan yang mempunyai efek bakterisid dan bakteriostatik terhadap berbagai macam bakteri, baik gram positif maupun gram negative tergantung dari konsentrasi yang digunakan. Chlorhexidine pada konsentrasi rendah dapat menyebabkan peningkatan permeabilitas pada sel bakteri sehingga terjadi kebocoran dari komponen interseluler bakteri, sedangkan pada konsentrasi tinggi dapat menyebabkan pengendapan sitoplasma bakteri sehingga terjadi kematian sel. ${ }^{1,23,24}$

Molekul chlorhexidine memiliki muatan positif (kation) dan sebagian besar muatan molekul bakteri adalah negative (anion). Hal ini menyebabkan perlekatan yang kuat dari chlorhexidine pada membran sel bakteri. Chlorhexidine akan menyebabkan perubahan pada permeabilitas membrane sel bakteri sehingga menyebabkan keluarnya sitoplasma sel dan komponen sel dengan berat molekul rendah dari sel menembus membran sel sehingga menyebabkan kematian bakteri. ${ }^{1,25}$

Chlorhexidine lebih efektif terhadap bakteri gggram positif dibandingkan terhadap bakteri gram negatif. Hal ini disebabkan oleh adanya perbedaan jenis dinding sel pada bakteri gram positif. Bakteri gram positif tidak memiliki lipopolisakarida sedangkan bakteri gram negatif memiliki lipopolisakarida. Lipopolisakarida mampu untuk menahan molekul kationik dari chlorhexidine sehingga membatasi dan mengurangi efektifitas kerjanya. Selain itu, membran luar dari bakteri gram negatif, bertindak sebagai penghalang terhadap zat anti bacterial yang bersifat kationik seperti chlorhexidine. , $25,26^{2}$

Bakteri Aggregatibacter actinomycetemcomitans (Aa) merupakan bakteri gram negative fakultatif anaerob bersifat non motil, tidak berspora, berbentuk basil, dan merupakan bakteri eksogen yang dapat menyebabkan infeksi sejati, dapat ditularkan antar individu yang terpajan oleh bakteri ini. Bakteri ini berperan dalam menyebabkan terjadinya periodontitis agresif dan periodontitis kronis. Bakteri ini dapat merusak jaringan dengan cara merangsang inflamasi, menyebabkan destruksi jaringan dan menghambat penyembuhan jaringan. Habitat asli bakteri ini adalah dalam rongga mulut. Bakteri lain yang dapat menyebabkan terjadinya penyakit periodontal ialah Porphyromonas gingivalis, prevotela intermedia, Fusobacterium nucleatum yang merupakan bakteri gram negatif. Namun, bakteri yang paling dominan yang ditemukan pada penderita periodontitis ialah bakteri Aggregatibacter actinomycetemcomitans (Aa). Bakteri ini memiliki fimbriae, vesikel, dan materi amorf ekstraseluler. Vesikel atau blebsmerupakan sifat utama dari Aggregatibacter actinomycetemcomitans (Aa) yang merupakan unit dari lipopolisakarida yang berhubungandengan membran luar. Leukotoksik memiliki sejumlah membran vesikel, dimana membran ini memiliki endoktoksin, bakteoriksin, adhesion, dan dapat meresorpsi tulang. 1,9, 19-21,27-31 
Air perasan buah lemon (Citrus limon(L.) Burm f) memiliki banyak senyawa bioaktif seperti flavonoid, karotenoid, limonoid, tannin, dan terpenoid yang memiliki sifat antibakteri. Air perasan buah lemon $25 \%$, 50\%, dan 100\% memiliki daya hambat terhadap pertumbuhan bakteri Aggregatibacter actinomycetemcomitans (Aa). Hal ini disebabkan oleh adanya senyawa bioaktif yang terkandung dalam air perasan buah lemon yang memiliki sifat antibakteri, seperti limonene, flavonoid, asam sitrat, dan tanin. Kandungan limonen dapat membunuh bakteri dengan cara merusak dinding sel, mengubah permeabilitas membran sel, dan menghambat stabilitas membran sel bakteri dan menunjukan sifat farmakologi yang baik. Senyawa flavonoid, berfungsi sebagai bakteriostatik yang dapat mendenaturasi protein sel bakteri dan merusak membran sitoplasma yang terdiri dari lipid dan asam amino sehingga inti sel bakteri juga akan lisis. Asam sitrat adalah asam organik yang terkandung paling banyak dalam air perasan jeruk lemon dengan derajat keasaman $(\mathrm{pH}) 2$ sampai 3 yang mengakibatkan $\mathrm{pH}$ pada sel bakteri menurun sehingga aktifitas sel bakteri terhambat. Sedangkan senyawa tanin menghambat pertumbuhan bakteri dengan cara menghambat aktivitas enzim protease pada proses transport protein sel bakteri dan menginaktivasi fungsi materi genetik protein enzim yang terdapat pada bakteri akan terdenaturasi sehingga metabolisme bakteri akan terganggu dan terhambat. ${ }^{1,13-14,32-35}$

Pada penelitian ini, rerata diameter zona hambat di sekitar cakram kertas pada 16 sampel air perasan buah lemon $25 \%$, 50\%, dan $100 \%$ adalah sebesar 2,89mm. Dapat disimpulkan bahwa air perasan buah lemon $25 \%$, 50\%, dan $100 \%$ memiliki daya antibakteri. Pada cakram kertas chlorhexidine, rerata diameter zona hambat adalah 3,30 mm. Dengan demikian, dapat disimpulkan bahwa chlorhexidine juga memiliki daya antibakteri. Lalu menurut David dan Stout, daya antibakteri dapat dibagi menjadi 4 kriteria. Jika diameter zona hambat $5 \mathrm{~mm}$ atau kurang dikategorikan lemah, diameter zona hambat 5-10 mm dikategorikan sedang, diameter zona hambat 10-20 mm dikategorikan kuat, dan zona hambat $20 \mathrm{~mm}$ atau lebih dikategorikan sangat kuat. Mengacu pada kriteria ini, maka diketahui bahwa air perasan buah lemon $25 \%$, 50\%, dan $100 \%$ dan chlorhexidine memiliki daya antibakteri yang lemah. . 36,37

Penelitian ini sesuai dengan penelitian yang telah dilakukan sebelumnya oleh Yoshiaki Miyake dan Masanori Hiramitsu yang menjelaskan bahwa subtansi antibakteri dari jeruk lemon dapat menghambat bakteri oral penyebab karies dan periodontitis, seperti Streptococcus mutans, Prevotella intermedia, dan Porphyromonas gingivalis. Selain itu, Natasya Angelyna Batubara juga telah membuktikan bahwa air perasan buah lemon (Citrus limon) memiliki antibakteri dan dapat menghambat jumlah koloni Staphylococcus aureus secara in vivo. , $15,16,18^{-1}$
Berdasarkan pembahasan diatas, maka hipotesis penelitian ini diterima, yaitu terdapat daya hambat air perasan buah lemon (Citrus limon (L.) Burm. f.) $25 \%$, 50\%, dan 100\% terhadap pertumbuhan bakteri Aggregatibacter actinomycetemcomitans (Aa).

\section{KESIMPULAN DAN SARAN}

Air perasan buah lemon (Citrus limon (L.) Burm. f.) dapat menghambat pertumbuhan bakteri Aggregatibacter actinomycetemcomitans (Aa). Perlu dilakukan penelitian lebih lanjut mengenai daya hambat air perasan buah lemon (Citrus limon (L.) Burm f.) 25\%, 50\%, dan 100\% terhadap bakteri patogen lain yang terdapat pada penyakit periodonsium mengenai efektivitas, metode uji aktivitas antibakteri yang berbeda dan pemeriksaan fitokimia untuk mengetahui senyawa bioaktif yang terdapat didalam air perasan buah lemon.

\section{DAFTAR PUSTAKA}

1. Paramita DC. Uji Daya Hambat Air Perasan Buah Lemon (Citrus Limon(L) Burn. F) 60\% terhadap Pertumbuhan Bakteri Aggregatibacter Actinomycetemcomitans. [Skripsi] Jakarta: FKG Universitas Prof.Dr. Moestopo (beragama): 2019, 1-2,45-49.

2. Anonim. Riset Kesehatan Dasar. Badan Penelitian dan Pengembangan Kesehatan Republik Indonesia. Laporan Nasional (RISKESDAS 2018). 2018: 197

3. Anonim. Pedoman Usaha Kesehatan Gigi Sekolah (UKGS). Kementerian Kesehatan RI. 2012. Diunduh dari http://pbpdgi.or.id/wp-content/uploads/2015/04/UKGS. pdf, tanggal 17 Januari 2019.

4. Newman M, Takei H, Klokkevold P, Carranza F. Carranza's Clinical Periodontology $11^{\text {th }} \mathrm{ed}$. Philadephia: WB Saunders Co. 2012: 452-456

5. Carranza FA. Newman MG, Takei HH. Carranza's Clinical periodontology. $10^{\text {th }}$ ed. Philadelphia: W.B. Saunders. 2006: 99-607

6. Lindhe J, Lang N, Karring T. Clinical Periodontology and Implant Dentistry. $5^{\text {th }}$ ed. Oxford: Blackwell Munksgaard. 2008: 428-458

7. Wolf H, Rateitschak E, Rateitschak K, Hassell T. Color Atlas of Dental Medicine: Periodontology. $3^{\text {rd }}$ ed. Stuttgart: Thieme. 2004: 82 .

8. Lang NP, Bartold PM, Cullinan M,Jeffcoat M, Mombelli A, et al. Consessus report: Aggressive periodontitis. Ann Periodontal. 1999: 4:53.

9. Raja M, Ummer F, Dhivakar CP. Aggregatibacter actinomycetemcomitans- A Tooth Killer ?. J Cli and Diagnostic Resc. 2014 ;8(8): 14-15

10. Brooks, G. F., Butel, J. S., Morse, S. A. Mikrobiologi Kedokteran. Jakarta: Salemba Medika. 2005: 234-235.

11. Ardila, C. M., Lopez, M. A. High Resistance Against Clindamycin, Metronidazole and Amoxicillin in Porphyromonas gingivalis and Aggregatibacter actinomycetemcomitans Isolates of Periodonsium Disease, Med Oral Patol Oral Cir Bucal. 15 (6): 947-51.

12. Sari MA . Daya Hambat Ekstrak Daun Belimbing 
Wuluh (Averrhoa bilimbi L.) Terhadap Pertumbuhan Streptococcus mutans, [Skripsi]. Jember: FKG Universitas Jember Bagian Mikrobiologi, 2013: 38

13. Shah R, Gayathri GV, Mehta DS. Application of Herbal Products in Management of Periodonsium Diseases: A Mini Review. Int J Oral Health Sci. 2015;5: 38-44

14. Russo M, Bonaccorsi I, Torre G, Saro M, Dugo P, and Modello L. Underestimated Sources of Flavonoids, Limonoids, and Dietary Fibre: Availability in Lemon's by-Products, J Funct Foods. 2014, (9): 18-26.

15. Berti PL. Daya Antibakteri Air Perasan Buah Lemon (Citrus limon (L.) Burm.F.) terhadap Porphyromonas gingivalis Dominan Periodontitis (In Vitro). [Skripsi]. Surakarta: FKG Universitas Muhammadiyah Surakarta, 2015: 4

16. Miyake Y, Hiramitsu M. Isolation and Extraction of Antimicrobial Substances Against Oral Bacteria from Lemon Peel. J Food Sci Technol. 2011. 48(5): 635-639

17. Newman MG, Takei HH, Klokkevold PR. Carranza's Clinical Periodontology. $12^{\text {th }}$ ed. Canada: Elsevier Saunders. 2015: 50-55.

18. Batubara NA. Efek Air Perasan Buah Jeruk Lemon (Citrus limon) terhadap Laju Aliran, Nilai $\mathrm{pH}$ Saliva dan Jumlah Koloni Staphylococcus aureus (In Vivo) [Skripsi]. Medan: FKG Universitas Sumatera Utara, 2017: 48

19. Tenggara FS, Rizka Y, Parsihni K. Daya Hambat Ekstrak Daun Sirsak (Annona muricata, Linn) terhadap Pertumbuhan Bakteri Mixed Periodontopatogen. Denta J Ked Gi. 2014; 8(2): 103-10.

20. Paliling A, Posangi J, Anindita PS. Uji Daya Hambat Ekstrak Bunga Cengkeh (Syzygium Aromaticum) Terhadap Bakteri Porphyromonas gingivalis. e-GIGI. 2016;4(2):229-34.

21. Marsh PD, Martin MV. Oral Microbiology. 5th ed. China: Churchill Livingstone Elsevier, 2009: 36-7; 120-32.

22. MalikR, ChangelaR,KrishanP, GugnaniS, BaliD. Virulence Factors of Aggregatibacter actinomycetemcomitans - A Status Update. J Int Clin Dent Research Organization. 2015; 7(2): 157-44.

23. Atmojo, AT. 2016. Media Mueller Hinton Agar. Diunduh dari https://medlab.id/media-mueller-hinton-agar.html, tanggal 28 Juli 2019

24. Parwani S, Rajkumar N, Himasnhu. Comparative Evaluation of Anti-Plaque Efficacy Of Herbal and 0,2\% Chlorhexidine Gluconate Mouthwash in A 4-Day Plaque Re-Growth Study. J Indian Society of Periodontology. $2013 ; 17$ (1)
25. Mevrayano, J., Rahmatini, dan E. Bahar. 2015. Perbandingan Efektivitas Obat Kumur yang Mengandung Chlorhexidine dengan Povidone Iodine terhadap S.mutans. Jurnal Kesehatan Andalas. 4(1): 168-171.

26. Cheung HY, Wong MM, Cheung SH, Liang LY, Lam YW, Chiu SK. Differential Actions of Chlorhexidine on The Cell Wall of Bacillus Subtilis and Escherichia coli. PLoS One 2012; 7(5): e36659.

27. Nikaido H, Vaara M. Molecular Basis of Bacterial Outer Membrane Permeability. Microbiological Review. 1985; 49: $1-32$.

28. Nørskov-Lauritsen N, Kilian M. Reclassification of Actinobacillus actinomycetemcomitans, Haemophilus aphrophilus, Haemophilusparaphrophilus and Haemophilus segnis as Aggregatibacter actinomycetemcomitans Gen. Nov., Comb. Nov., Aggregatibacter aphrophilus Comb. Nov. and Aggregatibacter segnis Comb. Nov., and Emended Description of Aggregatibacter aphrophilus to Include V Factor-Dependent and V Factor-Independent Isolates. Int J Syst Evol Microbiol. 2006 ; 56(9):2135-46.

29. Newman MG, Takei HH, Klokkevold PR. Newman and Carranza's clinical periodontology. 13th ed. Philadelphia: Elsevier, 2019: 114

30. MaliqR,ChangelaR,KirishanP, GugnaniS,BaliD. Virulence factors of Agregatibacter actinomycetemcomitans- A status update. JICDRO 2015; 7: 137.

31. Sriraman P, Mohanraj R, Neelakantan P. Aggregatibacter actinomyctemcomitans in Periodonsium Disease. Research Journal of Pharmaceutical, Biological and Chemical Sciences. 2014; 5(2); 406-419

32. $\mathrm{Zu} \mathrm{Y,} \mathrm{Yu} \mathrm{H,} \mathrm{Liang} \mathrm{L,} \mathrm{Fu} \mathrm{Y.} \mathrm{Activities} \mathrm{Of} \mathrm{Ten} \mathrm{Essential} \mathrm{Oils}$ Towards Propionibacterium acnes and Pc-3, A-549 And Mcf-7 Cancer Cells. J Molecules. 2010; (15): 3200-10.

33. Sokovic M. Antibacterial Effect Of The Essential Oils Of Commonly Consumed Medicinal Herbs Using An In Vitro Model. Molecules. 2010; 15(10): 7532-46.

34. Tomotake H, Koga T, Yamato M, Ota F. Antibacterial Activity of Citrus Fruit Juices Against Vibrio Species. $J$ Nutr Sci Vitaminol. 2006; 52: 157-60

35. Burt SA. Essential Oils: Their Antibacterial Properties and Potential Applications In Foods: A Review. Inter. J. Food Microbiol. 2004: 94: 223-253.

36. Brooks GF, Butel JS, Carroll KC, Morse SA. Jawetz, Melnick, \& Adelberg's Medical Microbiology. 24 $4^{\text {th }}$ ed. USA: Mc Graw Hill. 2007; 224-7

37. Greenwood. Antibiotic Susceptibility (Sensitivity) Test, Antimicrobial and Chemotherapy. USA: Mc Graw Hill Company. 1995 